\title{
Metaphorical Conceptualization of Food in Jordanian Arabic
}

\author{
Rose Aljanada \\ Northern Border University, Kingdom of Saudi Arabia \\ sakurarose31@gmail.com \\ Aseel Alfaisal \\ Northern Border University, Kingdom of Saudi Arabia \\ mrs.aseel@gmail.com
}

DOI: http://doi.org/10.36892/ijlls.v2i3.347

\begin{tabular}{|c|c|}
\hline $\begin{array}{l}\text { Received: } \\
\text { 04/07/2020 }\end{array}$ & $\begin{array}{c}\text { Abstract } \\
\text { This article studies the different food conceptual metaphors in }\end{array}$ \\
\hline $\begin{array}{l}\text { Accepted: } \\
\text { 26/08/2020 }\end{array}$ & $\begin{array}{l}\text { Arabic through the study of different food-related idioms and proverbs. A } \\
\text { corpus was built by collecting the largest possible number of food-related }\end{array}$ \\
\hline $\begin{array}{l}\text { Keywords: } \\
\text { conceptual metaphor } \\
\text { theory; } \\
\text { source domain; } \\
\text { target domain; } \\
\text { food metaphors; } \\
\text { Jordanian Arabic. }\end{array}$ & $\begin{array}{l}\text { a survey containing open-ended questions. The collected food-related idioms } \\
\text { and proverbs were categorized according to the target domain into which the } \\
\text { metaphors are mapped. Food in Jordanian Arabic food as a source domain } \\
\text { can be mapped into the following target domains: IDEAS, EXPERIENCE, } \\
\text { TEMPERAMENT, GAINING MONEY UNLAWFULLY, WINNING, } \\
\text { DECEIVING, COOPERATION, SCHEMING and TALKING NONESENSE. } \\
\text { These target domains form the following Conceptual Metaphors: IDEAS ARE } \\
\text { FOOD, GOING THROUGH AN EXPEREINCE IS EATING IT, } \\
\text { TEMPERAMENT IS FOOD, GAINING MONEY UNLAWFULLYISEATING } \\
\text { IT, WINNING IS EATING, DECEIVING IS MIXING INGREDIENTS, } \\
\text { COOPERATION IS SHARING FOOD, SCHEMING IS COOKING } \\
\text { TOGETHER ANd TALKING NONESENSE IS KNEADING. }\end{array}$ \\
\hline
\end{tabular}

\section{INTRODUCTION}

The word metaphor is derived from the Greek metaphora which means "transfer", which is translated in English as "to bear, or carry". According to the Merriam-Webster Online Dictionary, metaphor is defined as a figure of speech in which a word or phrase literally denoting one kind of object or idea is used in place of another to suggest a likeness or analogy between them, (Merriam-Webster Online Dictionary, n.d). Thus, metaphor stands for the conveyance of some kind of change.

Metaphors have been recognized as a rhetorical device that compares two seemingly different objects. Metaphors are conceptual processes which give the human conceptual system its form, (Negro, 2019, p1). A huge portion of our thoughts is directly affected and organized by metaphorical concepts. In 1980, George Lakoff and Mark Johnson presented the fields of linguistics and cognition with the Conceptual Metaphor Theory (CMT), in which they proposed a model to conceptualize metaphors. That model includes two domains: the first is a clear, concrete domain that is based on experience, called the "source domain". The other is an abstract domain called "target domain". Bridging the two domains together is "metaphorical mapping", a process that happens almost automatically and affects the way in which humans communicate with their surroundings, (Alsadi. 2017, p.113).

Food metaphors in Jordanian Arabic have been under investigation for some time. In his 2015 unpublished master thesis, A Study of Jordanian Proverbs Related to Food and Eating, Migdadi sets out to study proverbs related to food and eating in Jordanian Arabic. He categorizes the collected proverbs into four categories: a) proverbs related to the eating 
process itself, b) proverbs related to edible items, c) proverbs related to tools used in eating and d) proverbs related to the organs associated eating. He states that when it comes to semantic/ stylistic features, proverbs related to food and eating are similar to other kinds of proverbs regarding the use of figurative devices such as simile, metaphor, personification, metonymy, paradox, parallelism and other devices. When studying syntactic structures, Migadadi states that food proverbs are limited to specific syntactic structures such as imperative, interrogative and verb-less clauses, (Migdadi, 2015, p XII). However, Migadadi does not discuss food metaphors in Jordanian Arabic or how they can be conceptualized.

Another study that was conducted four years earlier, also an unpublished master thesis, $A$ Linguistic Study of Food and Drink Metaphors in North Jordan by Abed Al-Razzaq in 2011, investigates how metaphorical expressions of food and drinks are used in Northern Jordan. It also studies cultural-specific metaphorical patterns in conceptualizing food and drinks in Northern Jordan. Abed Al-Razzaq concludes that speakers of Jordanian Arabic recognize many abstract ideas through the use of metaphorical mapping (Abed Al-Razzaq, 2011, p xi). However, that study does not look into food as a source domain that can be mapped into target domains.

This current study attempts to pinpoint the different food conceptual metaphors in Jordanian Arabic through the study of different food-related idioms and proverbs.

\section{LITERATURE REVIEW}

Metaphors are about recognizing one thing in terms of another. We see our experiences which are more on the abstract level "target domain" in the light of the more concrete level "source domain". (Negro, 2019, p1). Dennis Tay (2014) points out that Lakoff 's Conceptual Metaphor Theory (CMT) can best be summarized in 3 terms:

1.The Conventionality Argument: metaphors are not solely used in creative writing or poetry, but also in everyday life situations.

2.The Conceptual Structure Argument: metaphors are not restricted to linguistics, they are also part of the study of cognition. Tay (2014) explained that:

"We don't only describe, but also understand one thing in terms of another by transferring or "mapping" knowledge about one concept (the

'source concept') to another (the 'target concept')", (pp.52-53).

3.The Embodiment Argument: source concepts are concrete but target concepts are abstract, (Tay, 2014, pp.52-53).

Lakoff and Johnson (1980) state that humans' conceptual system is in fact metaphorical in nature. To further clarify that notion, they proceed to give examples of concepts and conceptual metaphors in their book Metaphors We Live by; such as ARGUMENT IS A WAR, THEORIES (AND ARGUMENTS) ARE BUILDINGS, IDEAS ARE FOOD, IDEAS ARE PEOPLE, IDEAS ARE PLANTS, IDEAS ARE PRODUCTS, IDEAS ARE COMMODITIES, IDEAS ARE RESOURCES, IDEAS ARE MONEY, (pp.124-127).

Conceptual Metaphor Contrastive Studies indicate that conceptual metaphors and their subdivisions can be both universal and cultural-based. Alsadi (2017) reports that English and Arabic share conceptual metaphors like IDEAS ARE FOOD, TEMPERAMENT IS FOOD, GOING THROUGH AN EXPERIMENT IS TASTING IT. However, GAINING MONEY UNLAWFULLY IS DEVOURING IT is used in Arabic more than in English, (pp. 124-125).

Food Conceptual Metaphors help us see that so many aspects of life are experienced in terms of food. The mental processes used in "assimilating ideas" are to some extent understood and experienced in terms of "the more concrete transformations" that happen in the digestive system when absorbing food. Various metaphor domains are being investigated more and more because of their importance not only in language but in our thought processes. Food can serve as a metaphor for family, religion, science, sex, gender, social position, and group identity (Johnson, 1995, p.157). 
McGlone (1996) raised an interesting question: "How do people interpret metaphors such as The lecture was a three-course meal?" He provides two answers:

Lakoff (1993) has proposed that figurative expressions are interpreted as instantiations of deep conceptual metaphors, such as IDEAS ARE FOOD. In contrast, Glucksberg (1991) has proposed that metaphors are interpreted as assertions of the topic's (e.g., lecture) membership in an attributive category exemplified by the vehicle (e.g.,three-course meal). (p.544)

Moura (2006) provides us with two hypotheses to explain metaphors. First, he argues that conceptual and linguistic factors are "interdependent in the production and interpretation of metaphors". His second argument is that metaphors include a "compositional process". Metaphors present language users with new conceptual structures, (pp. 81-82).

It is not an easy task for researchers to study metaphors in Arabic since there are four major varieties of Arabic. The first is Classical Arabic (Al-Fusha / FA) which is the language of the Nobel Qur'an, the holy book for Muslims. Classical Arabic is used in formal contexts and taught informal settings. The second is the regional Colloquial Arabic varieties (Al'Amiya/ CA) which are unconsciously acquired and never taught or used in formal settings, (Maamouri, 1998, p.31). Colloquial Arabic is oral, rarely written, and Arabic speakers of different regions can understand some colloquial varieties (such as Colloquial Egyptian and Colloquial Syrian) which are easier than other varieties (such as Colloquial Moroccan or Darija), (Kaye, 2001, pp. 122-123). The third in-between variety is Modern Standard Arabic (MSA) which is used in media (spoken and written) and for official government work. The fourth variety is relatively new; the Educated Arabic (EA) which is used by educated Arabs with college/ university degrees for communication, (Zughoul,1980, pp. 203-206).

In order to study Food Conceptual Metaphors in Jordanian Arabic, it is important to first consider the work of one of the most well-known linguists of Classical Arabic (Al-Fusha), Abdulqader Aljurjani.

Hashim (1994) points out that Aljurjani defines metaphor as transferring the word from its meaning that it was known to others to another meaning. It is the use of the word in a way other than what was originally known to its users. For Aljurjani, this use is not fixed because it is "arriya / a:'ri:ya/" ; that is: borrowed, (p30). Classical Arabic (Al-Fusha) has two forms of metaphors according to Aljurjani:

1.True Metaphors (استعارة مُفيدة)/isteSara mufi:dəh/) which create new meaning when used. Aljurjani gave many examples of the True Metaphor, the simplest is /safahtu asadan/ I shook hands with a lion). A new, exaggerated meaning is introduced here with the use of the word lion to describe a man who is very brave.

2.Untrue Metaphors (استعارة غير مُفيدة / isteYara yeir mufi:dəh/) which do not create new

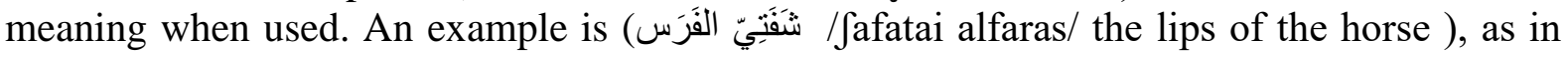
the verse:

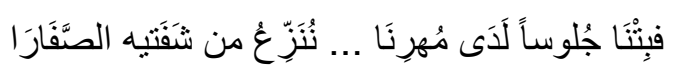

No new meaning was created in this metaphor since both humans and horses have mouths and lips, even though horses don't use theirs to talk, and that's why it is untrue for Aljurjani, (Hashim, 1994, pp.24-36).

In his article, Berrada (2007) compares food metaphor in Moroccan Arabic (the colloquial variety of Arabic spoken in Morocco) with its rather limited exploitation in Classical Arabic Qur'anic discourse. The researcher concludes that Qur'anic text does not seem to include instantiations of the IDEAS ARE FOOD metaphor. Thus, conceptual metaphors such as LEARNING IS EATING, UNDERSTANDING IS TASTING, UNDERSTANDING IS DIGESTING, and BELIEVING IS SWALLOWING, which are recurrent in many related and unrelated languages, are not instantiated in Qur'anic discourse, (p.10). 
Narrowing our study of metaphors in Arabic to Jordanian Arabic (the colloquial variety of Arabic spoken in Jordan), there is no way we can overlook the fact that Jordan is a very linguistically rich country where there are five main spoken dialects. Such richness and diversity ensure an ample supply of colloquial metaphors. These five dialects are:

1.The Bedouin dialect ('Badawi), spoken by Jordanians who come from Bedouin tribes and mostly live in the eastern parts of Jordan.

2.The Urban dialect ('Madani) which is used in Amman, the capital city of Jordan and in other major cities.

3.The Rural dialect (Fa'lahi) which is used in the rural areas especially in the northern parts, in cities like Irbid, Ajloun and Jerash.

4.The Southern dialect which is exclusively used in the southern parts of Jordan, in cities like Ma'an, Othruh and Aljafer.

5.The White dialect which is used for communication in case of different dialects. It contains vocabulary from MSA and is less influenced by tribal or rural vocabulary, (Alfaisal and Aljanada, 2019, pp.109-110).

\section{METHODOLOGY}

This article studies the different food conceptual metaphors in Jordanian Arabic through the study of different food-related idioms and proverbs. The researchers built a corpus by collecting the largest possible number of food-related idioms and proverbs used in Jordanian Arabic, regardless of the dialect, using a survey containing open-ended questions. Subjects were chosen randomly, all of whom speak Jordanian Arabic without specifying the dialect. They are required to mention the largest possible number of expressions (idioms or proverbs) related to food which they use in their daily life. The researchers then proceeded to categorize the collected food-related idioms and proverbs according to the target domain into which the metaphors are mapped.

\section{RESULTS AND DISCUSSION}

Analysing the collected data, food as a source domain in Jordanian Arabic can be mapped into the following target domains: IDEAS, EXPERIENCE, TEMPERAMENT, GAINING MONEY UNLAWFULLY, WINNING, DECEIVING, COOPERATION, SCHEMING and TALKING NONSENSE. These target domains form the following Conceptual Metaphors:

\subsection{Ideas are food}

This group of expressions found in Jordanian Arabic represents food idioms and proverbs that establish a similarity between ideas and food in the sense that both can be bitten, tasted, eaten, swallowed, digested and devoured, (Lakoff, 1980, p125).

a. هضم الفكرة/had'am əlfikra/ (He digested the idea). This means a person is completely certain that a point of view, an idea or a cause is true after they consider it for some time. This is used to refer to a person being fully convinced of something after taking their time thinking and examining it. The process of eating food is not complete until we digest that food. This process takes time and so is thinking. Once the food is completely digested, it is finally useful to the body. By the same comparison, once an idea is digested, now it is time to use it.

b. لحس مخي/lahas muxi:/ (He licked my brain). This means the speaker is so influenced by someone else's thoughts and way of thinking that they change their own decisions. This is used to refer to someone's great ability to influence the decisions other people make. Licking a plate is done to ensure that it is completely empty, no food remained. Licking someone's mind is 
simply making sure none of their own thinking remains so whatever imposed on them is accepted.

c. بلع السالفة /balaS əsa:lfəh/ (He swallowed the story). It means someone is convinced that a piece of information is true that they do not question its validity. This is usually used to refer to either how naïve a person is or how convincing the speaker is. If you swallowed a piece of food, you are done chewing it. You have it now in your digestive system and soon it will be used to nourish your body. So, if you swallow an idea, soon it will be part of your thinking. Unfortunately, it cannot only be a "good idea" but also a "bad idea". In this idiom, only naïve people accept food without checking its quality.

d. فكرتلك محروقة /fəkərtək mahru;gə/ (Your idea is burnt out). It means someone's idea or suggestion is previously mentioned or over-used. This is normally used to refer to old and no longer useful suggestions. In some cases, it is used to tell the one who suggests an idea that someone else has come up with the exact same idea. This idiom draws a similarity between burnt objects and ideas: what use is a burnt piece of furniture? And so is a burnt idea.

e. أنا عاجنته وخابزنه /ana Ca:dzəntu wa xabəztu / (I kneaded and baked him). This means the speaker knows this person so much that they know every little detail about his or her character and behavior. It is sometimes used to refer to someone's behavior is so predictable. This idiom points out the resemblance between the processes of kneading and baking and knowing someone. You need to practice kneading and baking in order to produce quality food, you need to understand the relationships between ingredients, temperature and liquids. The longer you spend in your endeavor to learn baking, the better you get. In the same manner, to fully understand someone you need to know his habits and thinking. The longer you spend knowing them, the more you understand them.

f. ما شبع دراسة /ma Jibiৎ dra:sə/ (He is not full studying). This means a person has not satiated their carving for more studying. This is used to describe someone who never stops studying, or someone who is obsessed with spending all of his time studying. This idiom uses the feeling of being full on your favourite food to refer to wanting more.

\subsection{Going through an experience is eating it}

This group of expressions found in Jordanian Arabic represents food idioms and proverbs that establish a similarity between going through an experience and eating or tasting it, in the sense that both are the result of putting something into the mouth, biting into it, chewing it and trying to swallow it. The process takes time, sometimes is not easy and could possibly damage one's teeth. Bitter food leaves an unpleasant taste and a lesson to never attempt eating it again.

a. أكل هوا /akal ha'wa/ (He ate air). This means a person has been dealt a hard blow either in life or in work. It is normally used to refer to coming to an undesirable end. Eating something unpleasant result in discomfort, and this experience stays with us for so long.

b. أكل الهم/akal əlham/ (He ate worries). This means someone so much worried about something that he gets anxious, possibly restless. This refers to the pain we sometimes have when we worry over something, a pain that can feel like something heavy is churning in one's stomach, making it difficult to breath. Going through this kind of experience (worry) is likened to eating food that does not suit one's stomach and so results in pain. 
c. أكل الكتب / Pkal olkutub/ (He ate the books). This means a person is in the habit of studying so hard that he devoured everything related to the subject he is currently studying. This is identical to the English metaphor in (He devoured the books). The process of eating or devouring that the "devourer/ person" goes through in this idiom ends with knowledge of some sort, be it academic or life-related.

d. أكل قتلذة / akal gatloh / (He ate a beating). This means someone was beaten. It is used to refer to a form of rough treatment as a form of punishment. Other times it is used to refer to the result of a fight. Some Jordanian dialects pair the same expression with the phrase نصها موت/nus'ha mo:t/ which literally means (He ate a beating, half of which was death). It means he was beaten so violently that he got hurt or injured.

e. ماكل عليه الدهر وشارب/makəl Cleih ədahr wa Ja:rəb/ (Time has eaten and drunk upon him). It sometimes refers to a very old, or very unlucky person because he has been dealt many blows in their life. It can also be used to refer to old-fashioned garments, obsolete computer systems, ramshackle buildings, very old furniture and even old ideas.

f. ذقتها /ðugtha/ (I tasted it). This means the speaker has gone through the same exact experience that is being narrated to him by some other person. Here, going through a life experience is, for the speaker, a tasting process during which he learns something. Most of the times, this expression is used to refer to "bitter" experiences.

g. ترباية الصبيان زي قرط الصوان/tirbaietəl sibja:n zai gart`əs uwa:n/ (Raising boys is like biting into flints). This is especially used to describe how raising children and especially boys can be difficult and time-consuming. This expression draws a picture in which boys need extra work to ensure that they will grow up into adults, and to do that parents are given a cautionary piece of advice: it is not easy. Imagine trying to bite into a piece of flint, if you did so with all your might, your teeth could simply get shattered, if you didn't, well, you would end up with nothing to eat!

\subsection{Temperament is food}

This group of expressions found in Jordanian Arabic represents food idioms and proverbs that establish a similarity between temperament and food in the sense that these expressions reflect the nature of some people. Some people are as sweet as honey, others are bitter. Some are hard to swallow, others you cannot guess at just as you cannot guess which is the right side of a lentil seed.

a. أكل راسي /akal rasi:/ (He ate my head). This means someone kept nagging me until I could not take it any longer and gave in as a result. It is normally used to justify why the speaker gave in and did something they did not mean to do, or to describe someone who keeps nagging all the time.

b. بوكل البسة وعشاها / bukəl əlbəsəh wa ؟ Ja:ha/ (He can eat both the cat and its dinner). This means someone is so shrewd to the point of doing unexpected things. It is generally used to refer to a person whose innocent appearance or behaviour is deceptive.

c. شارب روح الخل / شa:rəb ru:ћəlxl/ (He has drunk the vinegar spirit). This means someone has been through so much that he is all messed up. This person is no longer responsible for their actions and generally considered by most people to be hopelessly beyond help.

d. خبز الصاج مقلّب ع الوجهين/ خubzel sadz mgllab Sal widzein/ (Like Saj Bread, you cannot guess its front from back). Saj Bread is a homemade, tortillalike kind of bread that Jordanians traditionally make and consume at home. 
This means someone is insincere, dishonest, deceitful or deceptive. It is normally used to describe people we are better off without them because we are not sure of their intentions or whose side they will take.

e. لسانه يقطر عسل /ləsa:nuh jəgt§or Ssal/ (His tongue is dripping honey). It means a person is speaking sweetly or softly, or in a way that is intended to please, often without being sincere. It is used in Jordanian Arabic to give a negative description to a person. This can be very close to the English adjective (honey-tongued).

f. حلو لسان قليل إحسان/həlw ləsa:n gali:l ihsa:n/ (A sweet tongue and no good deeds). This means someone is known for his honey tongue and promises which he does not keep. It is normally used to describe people who sugarcoat reality in order to get what they want regardless of other peoples' loses.

g. لوة زي السكر/ holwei zai qasabelsukkar/ (She is as sweet as sugarcane). This means a woman is sweet-tempered. This is normally used to describe a woman or a girl who is very sweet-tempered, good-natured and does not get angry easily.

h. وجهو زي قلاية البندورة /widzhu zai galaiet elbandura/ (His face looks like cooked tomatoes). This means his face is very darkened, unsmiling or downright not pleasant to look at because he is angry, sullen or sulking over something.

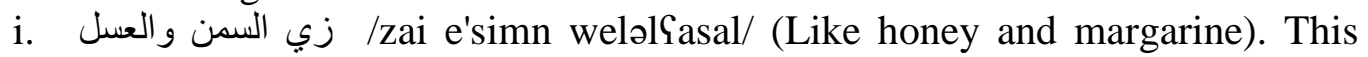
means two people or items go together as perfectly as honey and margarine do. It is usually used to describe the state of complete harmony that two people enjoy or two things are characterized with.

j. كونة/kamu:nəh/ (He is a cumin seed). This means a person is very stingy. This idiom use the state in which cumin seeds are usually in (dry and hard) in order to describe a person's behavior when it comes to money.

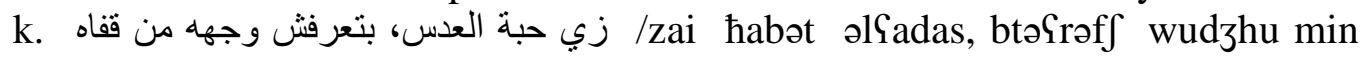
gafa:h/ (He is just like a lentil seed, you cannot guess its front from back). This means someone is insincere, dishonest, deceitful or deceptive. It is normally used to advise the listener to stay away from those whose intentions are not clear.

\subsection{Gaining money unlawfully is eating it}

This group of expressions found in Jordanian Arabic represents food idioms and proverbs that establish a similarity between unlawfully gaining money and eating. Arabic is much influenced by the language of the Nobel Qur'an. Similarly, colloquial Arabic uses many expressions used in the Qur'anic style. When it comes to foodrelated expressions, eating something that is not rightfully yours is unlawful gaining.

a. أكل حقي /akal hagi:/ (He ate my right). This means someone stole what is mine. This is used specifically to describe a person's rights, money, possessions or property being unlawfully seized.

b. أكل لحم كتافي / akal lahim ktafi/ (He ate the meat of my shoulders). This means someone has enjoyed the fruits of my hard work whereas I could not. This is used specifically to describe a person's money, possessions or property being taken advantage of or even ripped off.

c. بوكل كفن الميت/bukil kafanəl maiet/ (He eats the shroud of the dead). This means someone who is so opportunist that he has no shame taking advantage of the weak or the poor. It is used to describe unethical, dishonest or opportunist people who has no ethical code to prevent them from wrongdoing or financially deceiving people. This idiom is used as a form of warning to the listener to never trust this person. 


\subsection{Deceiving is mixing ingredients}

This group of expressions found in Jordanian Arabic represents food idioms and proverbs that establish a similarity between an attempt at deceiving someone and the process of mixing ingredients while cooking. Both take time, and both should be done to arrive at the result envisioned. In Jordanian Arabic, this is used in a negative sense most of the times.

a. بيدس السم بالعسل bidəs əssam bilGasal/ (He puts poison into honey). This means someone's intentions are malicious and that they try to provide other people with what appears to be harmless help but in reality, they have been scheming to get different results. It is normally used to warn us against falling for the seemingly sweet harmless schemes.

b. بيروب المي/biraw'ibəl mai/ (He makes yoghurt from water). This means someone is so deceitful that he can make yoghurt out of the water instead of using milk. This means a person can easily deceive others to the point where he or she can convince them of impossible things.

c. لاتبهر الموضوع / الكلام /la tbah'erəl maud`u:؟ - əlkla:m/ (Don't add a lot of spices in that). This is simply used as a piece of advice meaning "Do not exaggerate", given especially to people who tend to make up stories so they sound more interesting, or to people who are supposed to recount an incident but get taken away and add details that never actually happened. One cannot fail to notice that in this expression the "addition" of new ingredients can alter the original nature of things, which is the purpose of using spices in cooking: to change the taste. Sometimes, such an addition completely changes the nature of reality which in turn can be used to deceive others.

\subsection{Cooperation is sharing food}

This group of expressions found in Jordanian Arabic represents food idioms and proverbs that establish a similarity between cooperation and sharing. Sharing food in Islam is a sign of generosity and caring about others, and this is directly reflected in the Jordanian culture. Farmers share their meals in the field, people attending weddings and funerals bring food with them, neighbors invite each other for dinners. All of this is about sharing.

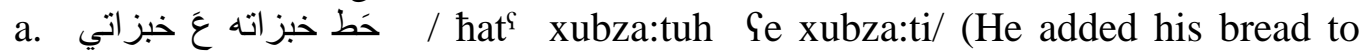
mine). This means a person shares their food (bread) with another. It is usually used to refer to cooperation between two people. The food they share together stands for the causes, issues or projects on which they agreed to work on together.

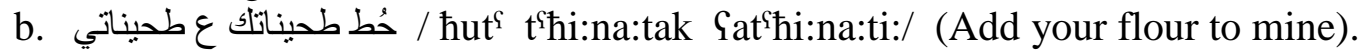
This means a person is advised to share their food (flour) with another. It is usually used to refer to cooperation between two people. The food they share together stands for the causes, issues or projects on which they agreed to work on together.

c. جيب قمحاتك ع قمحاتي / dzi:b gamћatak Sagamhati:/ (Add your wheat grains to mine). This means a person is advised to share their food (wheat) with another. It is usually used to refer to cooperation between two people. The food they share together stands for the causes, issues or projects on which they agreed to work on together. 


\subsection{SCHEMING IS COOKING TOGETHER}

This group of expressions found in Jordanian Arabic represents food idioms and proverbs that establish a similarity between schemes and cooking together. Cooking in secret is not perceived as "good" here, most of the time it is a secret plan that requires working in the dark to hurt someone.

a. طبخوها سوا أكلوها سوا Ifabaxu:ha sawa wa akalu:ha sawa/ (They cooked it together and they ate it together). This means a group of people have been scheming against another group of people or a person. It is usually used to warn a person of other peoples' ill intentions towards him or her if it is in the Future tense ( رح يطبخو ها سو اوياكلو ها سو ') /reh jt'abuxu:ha sawa wa jakalu:ha sawa/. If it is in the past tense, it provides explanation to what happened or to why these people have been together in a specific situation. Cooking is usually done in the kitchen, a specific place to do the different cooking processes like choosing ingredients, measuring, chopping, slicing, mixing, stirring, frying or roasting. It is done away from other people. So if a group of people cooked something together, it entails an agreement of some sort that only applies to them, and whatever results they get (the meal, in this case) is theirs only to eat.

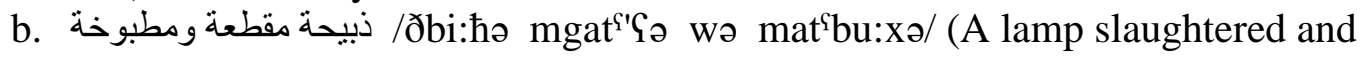
cooked). This means a group of people have been scheming against another group of people or a person. It is usually used to tell someone that a group of people have clearly had an agreement to do something, and whatever situation we face now is the result of that agreement. Butchering a lamp is no easy task, the animal needs to be taken to the slaughterhouse and tied before butchering it. This is a task that requires joint work. Cooking entails skinning, eviscerating the animal and butchering it into cuts which is also another task that requires working together. These two tasks represented in the idiom necessitate working together towards a common goal.

c. طابخين الموضوع من زمان / tha:bxi:nəl maud' u:؟ min zama:n/ (They cooked this thing a long time ago). This means a group of people have been scheming against another group of people or a person. It is usually used to tell someone that a group of people have clearly had an agreement to do something, and whatever dilemma faced now is the result of that agreement. Cooking is usually done in the kitchen, a specific place to do the different cooking processes like choosing ingredients, measuring, chopping, slicing, mixing, stirring, frying or roasting. It is done away from other people. So if a group of people cooked something together, it entails an agreement of some sort that only applies to them, and whatever results they get (the meal, in this case) is theirs only to eat. (من زمان/min zama:n/ a long time ago) indicates that whoever is part of this scheme has been working secretly, and most assuredly not in the positive sense, for so long.

\subsection{Winning is eating}

This group of expressions found in Jordanian Arabic represents food idioms and proverbs that establish a similarity between winning and the process of eating. Here, eating something, no matter how hard it is, is painted as a process that ends with a victory of some sort. One can emerge as the sole winner of a game or an argument.

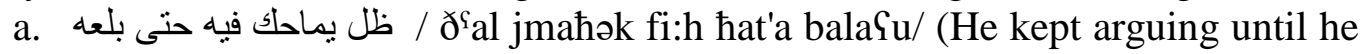
swallowed him). This means a person keeps arguing, defending their point of view, highlighting the advantages and generally making their opinion seem undisputed until the other party yields. This is used to describe people who 
never stops trying to convince others of their views. In this idiom, winning an argument is swallowing the "opposing" party and being done with.

b. اللي بيوكل ع ضرسه بينفع نفسه /i'li bjukəl Ca d`ors eats on his sprocket benefits himself). This means if you want a job done properly, do it yourself. This proverb is sometimes used as a form of advice to draw attention to the importance of getting involved in your own tasks and not waiting for others to do it because they might not do it well. Other times it is used as a form of warning, that if you do not work hard or if you are not responsible, you will not be rewarded. Here, eating using your sprockets is serious eating, it refers to hard work and involvement in one's duties and chores. The result of such hard work is the benefit you get: achieving your goals, doing your chores or winning something in return.

c. بتغدى فيه قبل ما يتعشى فيب /batyada fi:h gabil majitSafa fi'ji/ (I will eat him for lunch before he dines on me). This means you should be ready to attack and not wait for the other party to form their plans and force you into defense. This is used as a piece of advice if it is in the imperative form ( تغدى فيه قبل ما (يتعشى فيك /tyada fi:h gabil majitYafa fi:k/. If it is in the present as shown above, it refers to a plan being made. The idiom paints an image where attacks are meals and wining them is eating them earlier, you win only if you can eat that meal as a lunch and not wait too long.

\subsection{Talking nonsense is kneading}

This group of expressions found in Jordanian Arabic represents food idioms and proverbs that establish a similarity between useless speech and the process of kneading. Kneading takes a lot of time and effort on the part of the baker. Spending time talking about nonsense or repeating things over and over again is pictured as a kneading process that takes place in the mind of the listener but with no real outcomes.

a. بيلت وبيعجن/bilətu biYdzin/ (He jabbers and kneads). This means someone either keeps talking nonsense or keeps repeating the same sentences or ideas over and over again. It is normally used to describe someone who does not know when to stop talking especially when they try to convince other people to do something.

\section{CONCLUSION}

This paper has set out to study the different food conceptual metaphors in Jordanian Arabic through the study of different food-related idioms and proverbs. Analyzing the data obtained from native speakers of Jordanian Arabic, the researchers found out that Food in Jordanian Arabic as a source domain can be mapped into the following target domains: IDEAS, EXPERIENCE, TEMPERAMENT, GAINING MONEY UNLAWFULLY, TALKING NONSENSE, DECEIVING, COOPERATION, SCHEMING and WINNING. These target domains form the following Conceptual Metaphors: IDEAS ARE FOOD, GOING THROUGH AN EXPERIENCE IS EATING IT, TEMPERAMENT IS FOOD, GAINING MONEY UNLAWFULLY IS EATING IT, TALKING NONSENSE IS KNEADING, DECEIVING IS MIXING INGREDIENTS, COOPERATION IS SHARING FOOD, SCHEMING IS COOKING TOGETHER and WINNING IS EATING. Jordan is a very linguistically rich country where there are five main spoken dialects. Such richness and diversity ensure an ample supply of colloquial metaphors that use different source domains. The researchers call for further studies to tackle other items as source domains in Jordanian Arabic. For example, more research should be conducted to study the metaphorical conceptualization of colours, parts of the body, war, love and so many more. 


\section{REFERENCES}

Abed Al-Razzaq, A. A. (2011). A Linguistic Study of Food and Drink Metaphors in North Jordan (Unpublished Master's Thesis). Yarmouk University, Jordan.

Alfaisal, A. \& Aljanada, R. (2019). Diglossia in Arabic: Views and Opinions. The International Journal of Humanities and Social Sciences,7(5), 108-11.

Alsadi, H. (2017). English and Arabic Metaphorical Conceptualization of Food: A Contrastive Study. Arab World English Journal, 1, 112-126. http://dx.doi.org/10.24093/awejtls/vollno1.8

Berrada, K. (2007). Food metaphors: A contrastive approach. Metaphorik.de, 13(1), 1-38.

Hashim, Z.Y. (1994). Metaphor According to Abdulqader Aljurjani (Unpublished Master's Thesis). Um Alqura University, Saudi Arabia.

Johnson, M. (1995). Introduction: Why Metaphor Matters to Philosophy. Metaphor \& Symbolic Activity, 10(3), 157. https://doi-org.sdl.idm.oclc.org/10.1207/s15327868ms1003_1

Kaye, Alan. (1972). Remarks on Diglossia in Arabic: Well-defined vs. Ill-defined. Linguistics, 10(81), $32-48$.

Kaye, Alan. (2001). Diglossia: The State of the Art. International Journal of the Sociology of Language, 152, 117-129.

Lakoff, G. (1993). The contemporary theory of metaphor. In A. Ortony (Ed.), Metaphor and thought (pp. 202-251). New York: Cambridge University Press.

Lakoff, G., \& Johnson, M. (1980). Metaphors We Live by. Chicago: University of Chicago Press.

Maamouri, Mohamed. (1998). Language Education and Human Development Arabic Diglossia and its Impact on the Quality of Education in the Arab Region. Mediterranean development Forum, September 3-6 1998. Marrakech, Morocco.

Migdadi, H. F. (2015). A Study of Jordanian Proverbs Related to Food and Eating (Unpublished Master's Thesis). Yarmouk University, Jordan.

McGlone , M. (1996). Conceptual Metaphors and Figurative Language Interpretation: Food for Thought? Journal of Memory and Language, 35( 4), 544-565.

Metaphor. (2020). In Merriam Webster Online Dictionary. Retrieved from https://www.merriamwebster.com/dictionary/metaphor on June $16^{\text {th }} 2020$ at 00.09 .

Moura, H. (2006). The conceptual and the linguistic factors in the use of metaphors. D.E.L.T.A., 22(Especial), 81-93.

Negro, I. (2019). Metaphor and Metonymy in Food Idioms. Languages, 4,47, 1-8.

Tay, D. (2014). Gerorge Lakoff's Theory of Conceptual Metaphor. In Jeannette Littlemore \& John Taylor ( $1^{\text {st }}$ ed), The Bloomsburry Companion to Cognitive Linguistics (49-57). London, Bloomsburry Publishing Plc.

Zughoul, Muhammad. (1980). Diglossia in Arabic: Investigating Solutions. Anthropological Linguistics, 22(5), 201217. 


\section{APPENDIX (A)}

\section{Survey: Open-ended Questions- Original Version, in Arabic.} التعبيرات و الأمثال التي تستخدم مفردات الطعام في اللهجة الأردنية

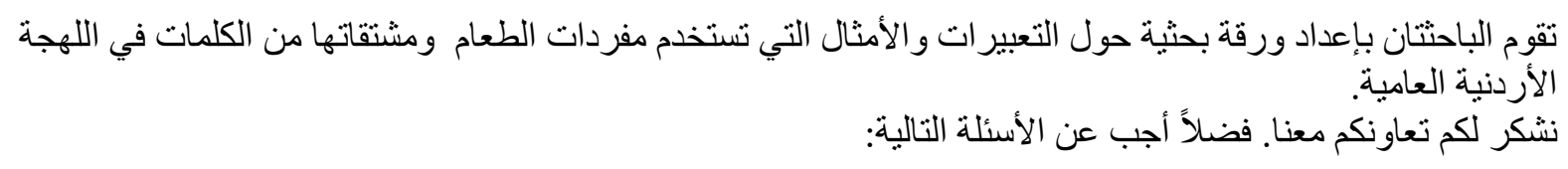




\section{APPENDIX (B) \\ Survey: Open-ended Questions- Translated Version, in English. \\ Idioms and Proverbs Which Use Food Vocabulary in Jordanian Arabic}

We are conducting a study about the idioms and proverbs which use food vocabulary in colloquial Jordanian Arabic. We would be grateful to you if you answer the following questions.

1. Write down the largest number of idioms and proverbs which you use in your dialect and which contain the verb (to eat).

2. Write down the largest number of idioms and proverbs which you use in your dialect and which contain the verb (to drink).

3. Write down the largest number of idioms and proverbs which you use in your dialect and which contain the verb (to cook) and any other (food preparation) verbs.

4. Write down the largest number of idioms and proverbs which you use in your dialect and which contain (kitchen utensils).

5. Write down the largest number of idioms and proverbs which you use in your dialect and which contain (eating verbs, drinking verbs, cooking and food preparation verbs and kitchen utensils) to describe people's character, habits, nature, appearance and manners. 


\section{AUTHORS'BIO}

Rose Aljanada is a lecturer at the Department of Languages and Translation, Arar Community College, Northern Border University. She holds a BA in English language Field Teacher, an MA in English language Teaching Methodologies. Her areas of interest are language acquisition, second language learning, foreign language learning, linguistics, comparative linguistic and psycholinguistics.

Aseel Alfaisal is a lecturer at the Department of Languages and Translation, Arar Community College, Northern Border University. She holds a BA in English language and literature, an MA in Linguistics. She is currently the Vice-dean of Academic Affairs at the Arar Community College for Girls, Northern Border University. Her areas of interest are phonetics and phonology, linguistics, sociolinguistics, Arabic dialects, comparative linguistic, educational leadership. 